\title{
United States and China: One evidence of the changing global geopolitical environment
}

\author{
Estados Unidos y China: Evidencia del cambiante entorno geopolítico mundial \\ Ruth Ortiz-Zarco ${ }^{a}$, Eusebio Ortiz-Zarco ${ }^{b}$, Gerardo Suárez Barrera $^{c}$
}

\begin{abstract}
:
This research paper examines the commercial and monetary interdependence that has been built during the period 1990 - 2018 between two main economies of the world; this is an empirical analysis, based on a statistical scrutiny of economic indicators and Granger causalty tests. The result is a contribution to the understanding of the $21^{\text {st }}$ century bundled international system, characterized by a changing global geopolitical environment, where the United States and China are the main actors.
\end{abstract}

Keywords:

Geopolitical Environment, Global Integration, Commercial Interdependence, Monetary Interdependence.

\section{Resumen:}

El presente trabajo de investigación examina la interdependencia comercial y monetaria que se ha forjado entre las dos principales economías del mundo, durante el periodo 1990 - 2018; se trata de un análisis empírico, sustentado en un escrutinio estadístico de indicadores económicos y pruebas de causalidad en el sentido de Granger. El resultado es un aporte a la comprensión del liado sistema internacional del siglo XXI, caracterizado por un cambiante entorno geopolítico mundial, del que Estados Unidos y China son los principales actores.

\section{Palabras Clave:}

Entorno Geopolítico, Integración Mundial, Interdependencia Comercial, Interdependencia Monetaria. .

\section{Introduction}

When addressing geopolitics, many and different areas of study are involved; however, this research work scope is limited to the analysis of commercial and monetary relations between two main actors of the new world order: the United States and China.

The economic component has become essential between both nations after the restoration of their bilateral relations in 1979. This work has a related specific objective: to determine, through statistical and econometric scrutiny, if the unfavorable trade balance, the high debt and the America's increasingly vulnerable monetary hegemony are supporting elements for China to be the current leader or the world economy.

There is an eminent degree of commercial correlation between the two countries: in 2016 , $8 \%$ of US exports were destined to China, which in turn became the main supplier of the United States, representing $21.4 \%$ of its imports in the same year; Total trade evolved from US \$ 2.5 million in 1979, to US \$ 648 million at the end of 2017. Regarding trade relations with Europe: since 2016 China has replaced the United States as the main trading partner of Germany, the biggest European economy, achieving in 2017 a bilateral trade of $\$ 230$ million. In addition, important economic projects that strengthens its geostrategic positioning are being developed, connecting the country with regions rich in raw materials, the most

\footnotetext{
a Autor de Correspondencia, Profesor investigador, programa educativo de comercio exterior, Universidad Autónoma del Estado de Hidalgo, https://orcid.org/0000-0002-7050-5181,Email:ruth_2608@hotmail.com

b Profesor investigador, Universidad Politécnica Metropolitana de Hidalgo, https://orcid.org/0000-0002-8617-7004, Email: eu.orti24@yahoo.com.mx

c Profesor investigador, programa educativo de comercio exterior, Universidad Autónoma del Estado de Hidalgo, https://orcid.org/00000003-1868-3658,_Email: gerardo_suarez@uaeh.edu.mx
} 
relevant is the so-called "The new silk route", to which the construction of the following railways is added: JakartaBandung, Addis Abada-Djibouti, China-Laos, HungarySerbia, the construction of the Melaka Gateway development in Malaysia; and the modernization of the Gwadar airport.

In the monetary field, there are some elements closely related to international trade to be discussed: China has recently begun to trade raw materials (mainly oil), in its own currency, which is seen by the United States as a challenge to the dollar, specifically to petrodollar which will be weakened by the strengthening of the yuan based on the increase in gold reserves in the central banks of China and Russia since 2008. Although the United States maintains the first place in gold reserves, according to World Gold Council, China and Russia were the main gold buyers in 2016 and 2017, ranking sixth and seventh worldwide respectively.

Regarding the United States external debt, it is growing rapidly, and today it is close to US $\$ 21$ billion; China has become its main creditor that owns US $\$ 1.05$ billion to February 2017, over a quarter of the Treasury bills. However, since 2013, China has been reducing its ownership of US treasury bonds, a measure that has direct impact on the monetary hegemony of the United States, because although the dollar is a global acceptance currency and the rest of the currencies align to it, the decline in the possession of US bonds by China allows the currency parity to weaken, favoring an appreciation of the yuan.

The elements previously discussed, lead us to put on doubt the position of the two most important economies in the world within the new world geopolitical order. To achieve the objective proposed on this introduction, four sections are incorporated into this research work an outline of a theoretical framework that explains the countries integration in the international system; a brief review of the related research work that precedes it; two sections of statistical and econometric analysis of the commercial and monetary links between the countries of study; and finally, the results and conclusions of this work are presented.

\section{Theoretical foundations of the global integration dynamics}

The clarification of the way in which a nation integrates into the world economic system that best suits the objective of this research is the theoretical and methodological proposal of Alejandro Dabat (1993), in which the following aspects of the capitalist system are pointed out : spatial structuring; national and international dynamics; and stages and spatial dimension. This section is a synthesis of the author's main ideas. [1]

a) Spatial structuring of capitalism.

Dabat conceives world capitalism as a complex system, consisting of a social structure and its spatial conformation, intertwined among themselves through capitalist production relations and their constant evolution, which in turn are determinants of the social and international division of work, a basis for the development of the economies. From the above three dissimilar social articulations are derived:

1. The spatial segmentation of the world economy, whose elements are linked to each other through the world market.

2. Structuring and integration of national capitalist societies.

3. Intersectoral relations that connect countries to each other.

The basic elements of world capitalism are national ones that compete with each other for trade and investment opportunities (containment is generated through their competitiveness and international positioning). National capitalisms are linked by the world market, involving various modes of production and capitalisms with different stages of development, but also pre-capitalist nations that must at least guarantee commercial relations are integrated, having to face important restructuring processes; Those peripheral societies that broke with the capitalist order but need their insertion into the world market are also incorporated.

The national market is the economic base of national capitalism, the territory is the most general basis of production and its determinants are: natural resources; fixed capital; physical infrastructure; population centers and labor force; social infrastructure; accumulated; and large technological knowledge consumer centers. In addition, the world market allows the exchange of goods, labor force and capital; but in turn, spreads internal economic crises and promotes commercial and military conflicts. The instability of the world market is remedied by the existence of an international states system that provides order to the nations, through the formation of blocks, hierarchies, alliances, organizations, diplomatic relations, agreements, treaties, etc. Dabat (1993). [1]

b) National and international capital dynamics. Dabat (1993) also states that in global terms, capitalism is determined by the interaction of endogenous motors and exogenous motors, located on different spatial planes. Both kinds of elements modify the existing social, economic and cultural conditions in an economy, and its mixture is very variable, depending on the historical time and the capitalist development phase of each country. 1 Endogenous engines are those intensive and extensive elements that foster national growth and the development of a capitalist economy. Extensive mechanisms are deployed in an economy with precapitalist conditions, and are reflected in the increase in the circulation and capital appreciation; some examples are: expansion of commercial relations, specialization of labor, capital accumulation without technological development, and government reforms.

Intensive mechanisms are characteristic of complex capitalism systems that qualitatively transform the regime of production and reproduction through increased productivity; product innovation; cost reduction and acceleration in the speed of capital circulation; industrial development; the elevation of the organic composition of 
capital; the acceleration of capital turnover; new productive transformations; changes in the production process; development of the credit system; development of telecommunications and transport; improvements in the education system; and the new forms of government regulation.

Exogenous motors are classified according to their either direct or indirect form of operation. The direct elements are: foreign trade, conquest, development of transport and telecommunications at international level, export of labor, capital and technology. On the other hand, military, scientific and technological development intervene as indirect exogenous motors.

c) Stages of capitalism.

The insertion of each state into the world market is determined according to the stage of development of its capitalism (see figure 1), and in turn, the successful overcoming of each stage depends on the internal conditions of the economy. The action of the world market on nations with different degrees of capitalist development (or with pre-capitalist conditions), generates qualitatively different consequences, granting dissident geopolitical status to each country or region.

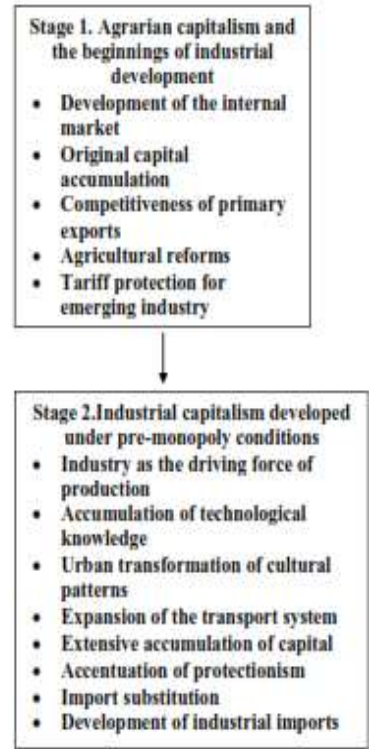

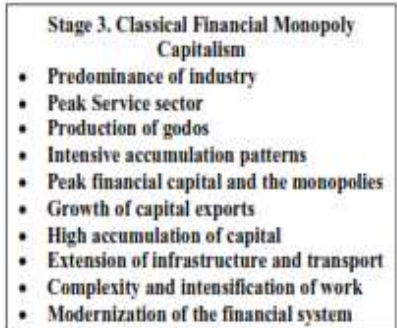

- Modernization of the financial system

\section{$\downarrow$}

Stage 4. State oligopolistic capitalist

- Production revolves around the

automotive sector and durable godos

Development of a comprehensive service infrastructure

- Intensive use of industrial capital

- Wide productive structure and urban

population

High productivity in manufacturing

- Expansion of the service sector

- Establishment of the welfare stat

Hegemony of the Lnited States

Internationat organization

Stage 5 . Computing and global capitalism in the precess of formation
- Restoration of the state
- Computing and cemumunications revolution
- Reconstruction of the work process
- Regilizanalizan of capital
- Deepening of capitalist reastions
- Internationalization of global problems

Figure 1. Stages of the development of the national capitalisms.

Source: Prepared by author based on Dabat (2013).

The theoretical approach of Dabat, shows the arguments to identify and explain the different stages of development of the capitalisms of the two most important economies in the world. China grew at an average annual rate of $10 \%$ for three decades until 2010; and after that year, its rate growth has slowed down; a situation that is explained by its need for abroad positioning of its surplus resources of production factors. China has overcome the extensive and intensive phases of capitalism at the domestic level, advancing to a phase of strengthening its exogenous growth engines through the international mobility of its production factors endowment.

By contrast, the capitalism of the United States is leaving the expansionary phase of the 1990s, where capital formation was favored in the high-tech sectors to the point of overinvestment, and the consequent profits fall. The government response to this situation was an expansionary monetary policy that attenuated the replacement of investment in favor of consumption, in such a way that the surplus achieved in the 90's has been transformed into the current account deficit this country is currently facing.

Bernanke (2005) postulated the hypothesis of an excess of global savings (global savings glut) as the origin of the deficit in the current account of the United States; the excess of savings in China has been moving to various countries for several years, where the ideal accommodation was the United States. Credit flows coincided with the detriment of investment in favor of consumption. The result is that the US economy needs to strengthen its endogenous engines now, strengthening its production schemes. [2]

\section{Stylized facts}

The United States - China relationship has been widely analyzed from several sides: there are those who believe that China's strength has been overvalued, (Sutter, 2007), and despite the changes in the international system, the United States continues to be the leader of the world economy, Thus China has little chance of becoming the hegemonic power of Asia and the world, Kang (2009); Other analysts state that US hegemony has eroded, while Chinese influence is on the rise and uses its progressive link with Latin American economies as a strategic part of its negotiations with the United States, Oviedo (2014). $[3,4,5]$

For Bendini (2016), China's economic rise represents a turnaround in international geopolitics and a strong challenge for the United States; China's growing economic and political weight provides it a relevant place within multilateral organizations; now both countries have great presence, and their interests make it difficult to find solutions for one of them without the other's consent; although the official position between the two countries is of mutual respect, in reality, the economic and political strategies of each one seem to be incompatible with those of the opposite: China pursues a new political and economic order that asserts its supremacy and the control of Asia, and the dilution of its vulnerability to the United States; which in turn refuses to lose its international preeminence. [6] 
Given this scenario, Xinbo (2011) argues that in order to ensure a strong, sustainable and growth balanced world; and given the high degree of interdependence between China and the United States, cooperation between the two nations is essential in the economic, financial, environmental, and political areas. This author also considers that the association between both nations must be genuine, based on respect for the interests of the counterpart, and with emphasis on the real economy instead of the virtual one (financial system). [7]

On the same order of ideas, Schell and Shirk (2017) state that currently, the relations between the United States and China are going through an unstable period: while the interdependence between them increases, China shows more assertive trade and economic policies that may affect key interests of the United States. A better scenario would be that both powers shared their power responsibilities, without becoming adversaries. [8]

Although the European economic crisis, and the protectionist policy driven by the United States current government, give China the opportunity to position itself in the new world order (Higueras, 2017), a hegemony transition still seems far away (Beeson and Li, 2015). Locating the geopolitical heart of the world is not a simple task; in the following section, some discussion is provided by analyzing the commercial and monetary relations between the two countries. $[9,10]$

\section{Trade relations between the United States and China}

Nowadays, there is a very close commercial link between China's economy and that of the United States. China is the main origin of the imports made by the US economy, exceeding US \$ 526 million in 2017; and the third destination for its exports, equivalent to US \$130 million in the same year, only surpassed by Mexico and Canada; Japan and Germany are two main trading partners for both of them, and maintain with them a deficit balance in their trade balances for both years (see tables 1 and 2). In 2017, the United States commercial trade deficit with the world exceeded US \$ 860 million, and exports grow currently at a higher rate than imports; Meanwhile, China has a positive balance in its trade with the world: in 2016 it generated more than US \$500 million, while in that same year the US trade deficit was very close to US $\$ 800$ million. Japan, the Republic of Korea and Germany have been the main suppliers of China in recent year, and its main export destinations behind the United States are Hong Kong, Japan and the Republic of Korea.

\begin{tabular}{cccccc}
\hline Partners & $\mathbf{2 0 1 5}$ & $\mathbf{2 0 1 6}$ & $\mathbf{2 0 1 7}$ & $\begin{array}{c}\text { Exports } \\
\mathbf{2 0 1 7}\end{array}$ & $\begin{array}{c}\text { Imports } \\
\mathbf{2 0 1 7}\end{array}$ \\
\hline \multirow{2}{*}{ World } & -811578 & -797751 & -862747 & 1546732 & 2409480 \\
& 705 & 652 & 301 & 881 & 182 \\
\hline \multirow{2}{*}{ Canada } & -21360 & -16190 & -24710 & 282471 & $\begin{array}{c}307181 \\
925\end{array}$ \\
& 257 & 600 & 244 & 681 & 925 \\
\hline
\end{tabular}

\begin{tabular}{|c|c|c|c|c|c|}
\hline Mexico & $\begin{array}{c}-63436 \\
733\end{array}$ & $\begin{array}{c}-67059 \\
857\end{array}$ & $\begin{array}{c}-74001 \\
950\end{array}$ & $\begin{array}{c}242988 \\
663\end{array}$ & $\begin{array}{c}316990 \\
613\end{array}$ \\
\hline China & $\begin{array}{c}-387956 \\
408\end{array}$ & $\begin{array}{c}-365913 \\
970\end{array}$ & $\begin{array}{c}-395818 \\
960\end{array}$ & $\begin{array}{c}130369 \\
530\end{array}$ & $\begin{array}{c}526188 \\
490\end{array}$ \\
\hline Japan & $\begin{array}{c}-72582 \\
550\end{array}$ & $\begin{array}{c}-71882 \\
713\end{array}$ & $\begin{array}{c}-72164 \\
294\end{array}$ & $\begin{array}{c}67695 \\
892\end{array}$ & $\begin{array}{c}139860 \\
186\end{array}$ \\
\hline UK & $\begin{array}{c}-2783 \\
731\end{array}$ & 127015 & 2238260 & $\begin{array}{c}56328 \\
789\end{array}$ & $\begin{array}{c}54090 \\
529\end{array}$ \\
\hline Germany & $\begin{array}{c}-77529 \\
165\end{array}$ & $\begin{array}{c}-67102 \\
130\end{array}$ & $\begin{array}{c}-66681 \\
835\end{array}$ & $\begin{array}{c}53492 \\
758\end{array}$ & $\begin{array}{c}120174 \\
593\end{array}$ \\
\hline
\end{tabular}

Table 1. Main USA trade partners.

(Balance of the Trade Balance / in thousand dollars)

Source: Prepared by author with TRADEMAP data (2019).

Table 3 shows the 8 primary products of bilateral trade between China and the United States; in 2017, 17.15\% of product imports by the United States came from China, an economy that in turn bought $8.51 \%$ of its imports from America; The two categories with the largest transactions are: Machines, devices, electrical equipment (electronic devices, TV, etc.) and their parts in the first instance; followed by Machines, mechanical devices, nuclear reactors, boilers and their parts (computers); To them is added the commercialization of land vehicles and their parts, plastic and their manufactures.

In addition to the products presented above, a bilateral commercial dependence is denoted, and it is reflected in the following transactions: The United States imports $48.49 \%$ of its consumption of toys, games and articles for recreation or sports from China; $43.39 \%$ of medicalsurgical furniture, $35.42 \%$ of knitted garments, $37.12 \%$ of garments (except knitted ones), $27.74 \%$ of machines, appliances and electrical equipment; and $25.19 \%$ of machines, devices and mechanical devices.

\begin{tabular}{|c|c|c|c|c|c|}
\hline Partners & 2014 & 2015 & 2016 & $\begin{array}{c}\text { Exports } \\
2016\end{array}$ & $\begin{array}{c}\text { Imports } \\
2016\end{array}$ \\
\hline World & $\begin{array}{c}383058 \\
071\end{array}$ & $\begin{array}{c}593903 \\
899\end{array}$ & $\begin{array}{c}509716 \\
484\end{array}$ & $\begin{array}{c}2097637 \\
172\end{array}$ & $\begin{array}{c}1587920 \\
688\end{array}$ \\
\hline $\begin{array}{l}\text { United } \\
\text { States }\end{array}$ & $\begin{array}{c}237034 \\
736\end{array}$ & $\begin{array}{c}261286 \\
188\end{array}$ & $\begin{array}{c}250557 \\
626\end{array}$ & $\begin{array}{c}385677 \\
759\end{array}$ & $\begin{array}{c}135120 \\
133\end{array}$ \\
\hline $\begin{array}{l}\text { Hong } \\
\text { Kong }\end{array}$ & $\begin{array}{c}350455 \\
770\end{array}$ & $\begin{array}{c}317716 \\
974\end{array}$ & $\begin{array}{c}270550 \\
995\end{array}$ & $\begin{array}{c}287251 \\
662\end{array}$ & $\begin{array}{c}16700 \\
667\end{array}$ \\
\hline Japan & $\begin{array}{c}-13529 \\
172\end{array}$ & $\begin{array}{c}-7286 \\
130\end{array}$ & $\begin{array}{c}-16402 \\
201\end{array}$ & $\begin{array}{c}129268 \\
487\end{array}$ & $\begin{array}{c}145670 \\
688\end{array}$ \\
\hline $\begin{array}{l}\text { Republic } \\
\text { of Korea }\end{array}$ & $\begin{array}{c}-89775 \\
322\end{array}$ & $\begin{array}{c}-73219 \\
699\end{array}$ & $\begin{array}{c}-65267 \\
428\end{array}$ & $\begin{array}{c}93707 \\
103\end{array}$ & $\begin{array}{c}158974 \\
531\end{array}$ \\
\hline Germany & $\begin{array}{c}-32309 \\
711\end{array}$ & $\begin{array}{c}-18468 \\
527\end{array}$ & $\begin{array}{c}-20894 \\
999\end{array}$ & $\begin{array}{c}65214 \\
031\end{array}$ & $\begin{array}{c}86109 \\
030\end{array}$ \\
\hline Vietnam & $\begin{array}{c}43823 \\
616\end{array}$ & $\begin{array}{c}36185 \\
275\end{array}$ & $\begin{array}{c}23922 \\
493\end{array}$ & $\begin{array}{c}61094 \\
097\end{array}$ & $\begin{array}{c}37171 \\
604\end{array}$ \\
\hline \multicolumn{6}{|c|}{$\begin{array}{l}\text { Table 2. Main China trade partners. } \\
\text { e of the Trade Balance / in thousand dollars). } \\
\text { : Prepared by author with TRADEMAP data }\end{array}$} \\
\hline
\end{tabular}

(2019). 
China obtains $58.17 \%$ of its imports of aircraft, space vehicles, and their parts from the United States; $37.68 \%$ of the seeds, oleaginous fruits, diverse fruits and industrial or medicinal plants; and $22.05 \%$ of wood pulp, cellulosic fibrous materials and paper or cardboard for recycling, (See table 3).

In addition to the products presented above, a bilateral commercial dependence is denoted, and it is reflected in the following transactions: The United States imports $48.49 \%$ of its consumption of toys, games and articles for recreation or sports from China; $43.39 \%$ of medicalsurgical furniture, $35.42 \%$ of knitted garments, $37.12 \%$ of garments (except knitted ones), $27.74 \%$ of machines, appliances and electrical equipment; and $25.19 \%$ of machines, devices and mechanical devices.

China obtains $58.17 \%$ of its imports of aircraft, space vehicles, and their parts from the United States; $37.68 \%$ of the seeds, oleaginous fruits, diverse fruits and industrial or medicinal plants; and $22.05 \%$ of wood pulp, cellulosic fibrous materials and paper or cardboard for recycling, (See table 3).

\begin{tabular}{|c|c|c|c|c|c|}
\hline Product & $\begin{array}{c}\text { FROM } \\
\text { China }\end{array}$ & $\begin{array}{c}\text { Total } \\
\%\end{array}$ & Product & $\begin{array}{c}\text { FROM } \\
\text { USA }\end{array}$ & $\begin{array}{c}\text { Total } \\
\%\end{array}$ \\
\hline All products & $\begin{array}{l}385 \\
677 \\
759 \\
\end{array}$ & 17.15 & All products & $\begin{array}{c}135120 \\
133\end{array}$ & 8.51 \\
\hline $\begin{array}{l}\text { Machinesap } \\
\text { pliances and } \\
\text { electrical } \\
\text { equipment, } \\
\text { and their } \\
\text { parts }\end{array}$ & $\begin{array}{c}93158 \\
470\end{array}$ & 27.74 & $\begin{array}{l}\text { Machinesa } \\
\text { ppliances } \\
\text { and } \\
\text { electrical } \\
\text { equipment, } \\
\text { and their } \\
\text { parts }\end{array}$ & $\begin{array}{c}15829 \\
194\end{array}$ & 3.83 \\
\hline $\begin{array}{l}\text { Machinesap } \\
\text { pliances and } \\
\text { mechanical } \\
\text { devices, and } \\
\text { their parts }\end{array}$ & $\begin{array}{c}79462 \\
404\end{array}$ & 25.19 & $\begin{array}{l}\text { Machinesa } \\
\text { ppliances } \\
\text { and } \\
\text { mechanical } \\
\text { devices, } \\
\text { and their } \\
\text { parts }\end{array}$ & $\begin{array}{c}14507 \\
915\end{array}$ & 9.83 \\
\hline $\begin{array}{l}\text { Medical and } \\
\text { surgical } \\
\text { furniture; } \\
\text { Bedding and } \\
\text { lighting } \\
\text { equipment }\end{array}$ & $\begin{array}{c}27392 \\
906\end{array}$ & 43.39 & $\begin{array}{l}\text { Seeds and } \\
\text { oleaginous } \\
\text { fruits; } \\
\text { various } \\
\text { seeds and } \\
\text { fruits }\end{array}$ & $\begin{array}{c}14430 \\
027\end{array}$ & 37.68 \\
\hline $\begin{array}{l}\text { Garments } \\
\text { and } \\
\text { accessories } \\
\text { (accessories } \\
\text { ), clothing, } \\
\text { knitted }\end{array}$ & $\begin{array}{c}16094 \\
992\end{array}$ & 35.42 & $\begin{array}{l}\text { Motor } \\
\text { vehicles, } \\
\text { tractors, } \\
\text { and other } \\
\text { land } \\
\text { vehicles, } \\
\text { and their } \\
\text { parts }\end{array}$ & $\begin{array}{c}13983 \\
518\end{array}$ & 19.56 \\
\hline $\begin{array}{l}\text { Toys, games } \\
\text { and articles } \\
\text { for } \\
\text { recreation or } \\
\text { sports; its } \\
\text { parts }\end{array}$ & $\begin{array}{c}14769 \\
535\end{array}$ & 48.49 & $\begin{array}{l}\text { Aircraft, } \\
\text { space } \\
\text { vehicles, } \\
\text { and their } \\
\text { parts }\end{array}$ & $\begin{array}{c}13285 \\
231\end{array}$ & 58.17 \\
\hline $\begin{array}{l}\text { Garments } \\
\text { and } \\
\text { accessories } \\
\text { (accessories } \\
\text { ), of clothing, }\end{array}$ & $\begin{array}{c}14320 \\
208\end{array}$ & 37.12 & $\begin{array}{l}\text { Optical, } \\
\text { photograph } \\
\text { y or } \\
\text { cinematogr } \\
\text { aphy, } \\
\text { measuring, }\end{array}$ & $\begin{array}{c}11188 \\
694\end{array}$ & 12.07 \\
\hline
\end{tabular}

\begin{tabular}{|c|c|c|c|c|c|}
\hline $\begin{array}{l}\text { other than } \\
\text { knitted }\end{array}$ & & & $\begin{array}{l}\text { control or } \\
\text { precision } \\
\text { instruments }\end{array}$ & & \\
\hline $\begin{array}{l}\text { Motor } \\
\text { vehicles, } \\
\text { tractors, } \\
\text { velocipedes } \\
\text { and other } \\
\text { land } \\
\text { vehicles }\end{array}$ & $\begin{array}{c}13910 \\
714\end{array}$ & 4.88 & $\begin{array}{l}\text { Plástic \& its } \\
\text { manufactur } \\
\text { es }\end{array}$ & $\begin{array}{c}6085 \\
147\end{array}$ & 9.97 \\
\hline
\end{tabular}

Table 3. Bilateral trade between USA \& China (main products).

Source: Prepared by author with TRADEMAP data (2019).

The trade balance with the rest of the world is negative for the United States and favorable for China, but the roles are reversed when talking about trade in services. Figures 2 and 3 summarize the total exchange of products and services for both countries, expressed in thousands of dollars; the first figure shows the imports path (IMP EU) and exports path (EXP EU) of the United States, in comparison with imports (IMP $\mathrm{CHI}$ ) and exports (EXP CHI) of China, for the period: 2001-2016.

Figure 2 shows a synchronized behavior among the four variables: at the beginning of the period the EU IMP far exceeded the CHI EXP, but in 2016 its value is very close, if the trend continues, in a few years the CHI EXP will exceed to the EU IMP; EU IMPs grows at a faster rate than EU EXPs, in contrast, EXP CHI rise faster than IMP $\mathrm{CHI}$. The subprime financial crisis had a strong negative impact on the trade in products, the recovery occurred as of 2010 and reversed in 2015, due to the fall in BRICS imports, the collapse of prices of primary products and oil, instability of financial and exchange markets.

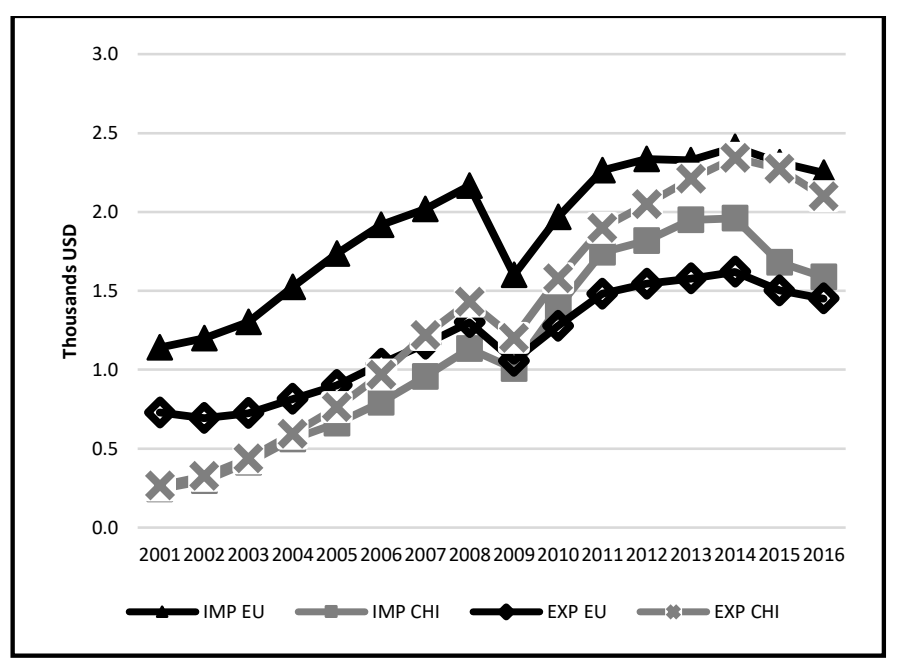

Source: Prepared by author with TRADEMAPE data (2018).

Figure 2. Product Exports \& Imports: USA \& China. 


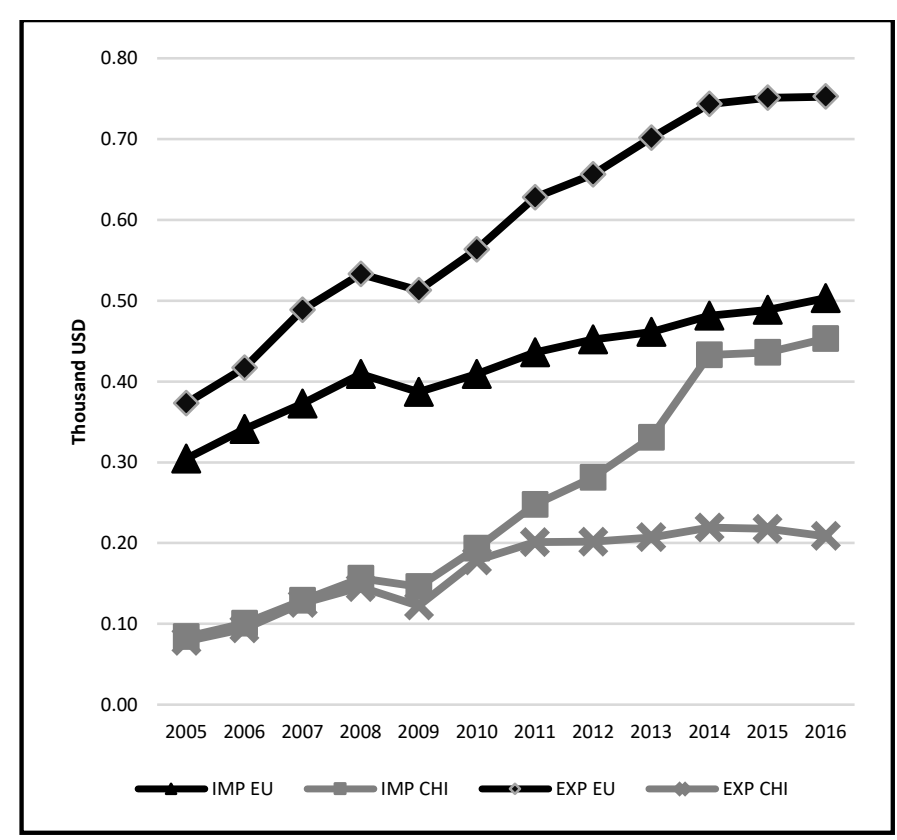

Figure 3. Service Exports \& Imports: USA \& China.

Source: Prepared by author with TRADEMAPE data (2018).

Trade in services was not affected by the situation mentioned above, although there was a slight fall due to the subprime financial crisis, as of 2010 the trend of exports and imports of services by the United States is growing, as that the Chinese exports, the imports of the Asian country are those that show a lower growth rate in the whole period analyzed and the last two years a negative propensity, (see figure 3).

The favorable balance of the United States in trade in services does not correct its deficit in trade in products; compared to China, the United States has commercial strength as transactions with services, mainly those involved in trade and travel to complement and strengthen the analysis, the Granger causality relations are estimated between: IMP CHI -IMP EU, EXP CHI - EXP EU, EXP CHI - IMP EU and EXP EU - IMP for this purpose annual export data and total imports of both countries are handled for the period 1990-2016, the data is obtained from the World Bank (WB). The exploration of the presence of unit roots, a prior and forced step to the Causality test, is performed through Augmented DickeyFuller tests applied to the 4 series, which become stationary in first differences (see table 4); confirmed the fact that these are stationary series of order (I), the causality ratio is estimated, with a significance level of $5 \%$ and in 4 delays, (see tables 5 and 6 ).

\begin{tabular}{|c|c|c|c|c|}
\hline \multicolumn{5}{|c|}{ Augmented Dickey-Fuller / Test for Unit Root in level } \\
\hline & EXP EU & IMP EU & EXP CHI & IMP CHI \\
\hline \multirow{2}{*}{ Intercept } & -1.19768 & -1.467830 & -1.916495 & -2.125651 \\
\hline & 0.6597 & 0.5336 & 0.3200 & 0.2368 \\
\hline \multirow{2}{*}{$\begin{array}{l}\text { Trend } \\
\text { and } \\
\text { intercept }\end{array}$} & -2.059611 & -1.207882 & 0.218353 & -0.356920 \\
\hline & 0.5430 & 0.8877 & 0.9968 & 0.9839 \\
\hline \multirow{2}{*}{ None } & 3.784995 & 3.279274 & 5.859373 & 5.736335 \\
\hline & 0.9998 & 0.9994 & 1.0000 & 1.0000 \\
\hline \multicolumn{5}{|c|}{$\begin{array}{l}\text { Augmented Dickey-Fuller / Test for Unit Root in 1st } \\
\text { difference }\end{array}$} \\
\hline & EXP EU & IMP EU & EXP CHI & IMP CHI \\
\hline \multirow{2}{*}{ Intercept } & -4.518512 & -5.118148 & -2.951127 & -3.351706 \\
\hline & 0.0015 & 0.0004 & 0.0407 & 0.0231 \\
\hline \multirow{2}{*}{$\begin{array}{l}\text { Trend } \\
\text { and } \\
\text { intercept }\end{array}$} & -4.546515 & -5.556299 & -2.412677 & -3.931550 \\
\hline & 0.0069 & 0.0007 & 0.0423 & 0.0257 \\
\hline \multirow{2}{*}{ None } & -3.279159 & -3.678202 & -1.902808 & -2.064329 \\
\hline & 0.0021 & 0.0007 & 0.0358 & 0.0396 \\
\hline
\end{tabular}

Table 4. Dickey-Fuller Test EXP EU, IMP EU, EXP CHI, IMP CHI

Source: Prepared by author with Eviews data.

In the short and medium term, there is a two-way causal relationship between US exports and Chinese exports (see table 5), their external demands are closely linked, and much of the goods that China exports to the United States, become re-exports of the latter country to Mexico and Canada mainly; re-exports enter into chapters 84 and 85 of the General Import and Export Tax Law (television screens, computers, cell phones, etc.).

\begin{tabular}{|c|c|c|c|c|}
\hline \multicolumn{5}{|c|}{ Granger Causality Test } \\
\hline Lags & Null Hypotesis & F-Statistic & Prob. & Decision \\
\hline 1 & $\begin{array}{c}\text { EXPEU does not } \\
\text { Granger Cause } \\
\text { EXPCHI }\end{array}$ & 19.2656 & 0.0002 & No Causalty \\
\hline 1 & $\begin{array}{c}\text { EXPCHI does not } \\
\text { Granger Cause } \\
\text { EXPEU }\end{array}$ & 10.4763 & 0.0036 & No Causalty \\
\hline 2 & $\begin{array}{l}\text { EXPEU does not } \\
\text { Granger Cause } \\
\text { EXPCHI }\end{array}$ & 7.93133 & 0.0029 & No Causalty \\
\hline 2 & $\begin{array}{c}\text { EXPCHI does not } \\
\text { Granger Cause } \\
\text { EXPEU }\end{array}$ & 5.37290 & 0.0136 & No Causalty \\
\hline 3 & $\begin{array}{l}\text { EXPEU does not } \\
\text { Granger Cause } \\
\text { EXPCHI }\end{array}$ & 5.97115 & 0.0057 & No Causalty \\
\hline 3 & $\begin{array}{c}\text { EXPCHI does not } \\
\text { Granger Cause } \\
\text { EXPEU }\end{array}$ & 3.71088 & 0.0321 & No Causalty \\
\hline 4 & $\begin{array}{l}\text { EXPEU does not } \\
\text { Granger Cause } \\
\text { EXPCHI }\end{array}$ & 5.73245 & 0.0060 & No Causalty \\
\hline 4 & $\begin{array}{c}\text { EXPCHI does not } \\
\text { Granger Cause } \\
\text { EXPEU }\end{array}$ & 2.75782 & 0.0699 & Causalty \\
\hline
\end{tabular}




\begin{tabular}{|c|c|c|c|c|}
\hline \multicolumn{5}{|c|}{ The Granger Causality Test } \\
\hline Lags & Null Hypotesis & F-Statistic & Prob. & Decision \\
\hline 1 & $\begin{array}{l}\text { IMPEU does not } \\
\text { Granger Cause } \\
\text { IMPCHI }\end{array}$ & 0.01447 & 0.9053 & Causalty \\
\hline 1 & $\begin{array}{l}\text { IMPCHI does } \\
\text { not Granger } \\
\text { Cause IMPEU }\end{array}$ & 1.35878 & 0.2557 & Causalty \\
\hline 2 & $\begin{array}{c}\text { IMPEU does not } \\
\text { Granger Cause } \\
\text { IMPCHI }\end{array}$ & 2.51041 & 0.1065 & Causalty \\
\hline 2 & $\begin{array}{l}\text { IMPCHI does } \\
\text { not Granger } \\
\text { Cause IMPEU }\end{array}$ & 0.36063 & 0.7017 & Causalty \\
\hline 3 & $\begin{array}{l}\text { IMPEU does not } \\
\text { Granger Cause } \\
\text { IMPCHI }\end{array}$ & 2.27368 & 0.1168 & Causalty \\
\hline 3 & $\begin{array}{l}\text { IMPCHI does } \\
\text { not Granger } \\
\text { Cause IMPEU }\end{array}$ & 0.07616 & 0.9720 & Causalty \\
\hline 4 & $\begin{array}{l}\text { IMPEU does not } \\
\text { Granger Cause } \\
\text { IMPCHI }\end{array}$ & 2.27041 & 0.1134 & Causalty \\
\hline 4 & $\begin{array}{l}\text { IMPCHI does } \\
\text { not Granger } \\
\text { Cause IMPEU }\end{array}$ & 0.19022 & 0.9395 & Causalty \\
\hline
\end{tabular}

Source: Prepared by author with Eviews data.

The Granger causality tests applied to imports from the United States and China, discard the presence of a causality relationship between both variables (see table 6 ), this is explained because more than $70 \%$ of the domestic demand of the Asian country is covered with domestic production and, in general, imports represent a link in the global production chains; unlike the United States, whose internal demand is mostly satisfied with external products; Chinese imports come mainly from South Korea (integrated circuits and cars) and Japan (cars and integrated circuits), while the dynamics of US imports are mainly based on China, Mexico and Canada. The commercial link between the two countries is close and relevant not only under the bilateral condition, but internationally, since both of them, for several years now, have been fighting for global hegemony in the economic, commercial and financial fields mainly; At the moment, it is still difficult to establish with certainty who precedes whom, but it is clear that the political, economic and commercial ties that both countries have forged with the rest of the world, place them in the gravitational center of the global economy, for such reason, the relationship that coexists between them is defining for any international event.

\section{Monetary relations United States - China}

In this part of the document the monetary links between the two countries are studied, based on the following elements: national debt, exchange rate, and monetary hegemony or dependence. Starting our analysis with the debt area, as of April 2018, the national debt of the United States (US $\$ 21.1$ billion) is slightly more than nine times that of China (US $\$ 2$ billion); however, in per capita terms, the United States debt is 34 times the one from China. In addition to the above stated, China is currently the largest holder of US treasury bonds: in November 2017, its holdings amounted to US $\$ 1.2$ trillion, this position is shared with Japan for some time periods with a tiny discrepancy from each other.

\begin{tabular}{ccc}
\hline & National Debt & Per cápita debt \\
\hline $\begin{array}{c}\text { United } \\
\text { States }\end{array}$ & 21175180795834 & 64586.53 \\
\hline China & 2315728055501 & 1634.55 \\
& $\begin{array}{c}\text { Public Debt } \\
\text { GDP }\end{array}$ & $\begin{array}{c}\text { External Debt \% } \\
\text { GDP }\end{array}$ \\
United & $72.70 \%$ & $97.74 \%$ \\
States & $20.32 \%$ & $14.04 \%$ \\
China & &
\end{tabular}

Table 7. USA \& China National Debt (in dollars) june 2018

Source: Prepared by author with US Debt Clock data (2018).

As at the time the dollar was a component that boosted the hegemony of the US economy; today, China's policies have strengthened the yuan and restricted Chinese monetary dependence against the dollar; both measures are key to its global positioning; Recently, China's monetary policy have shown greater autonomy compared to that of the United States. In March 2018, the Shanghai International Energy Exchange launched a new financial product called "petroyuan", which consists of oil futures contracts in yuan. In addition, and jointly, the Chinese interest rate moves independently; this fact undoubtedly strengthens the yuan and transfers instability to the dollar. Figure 4 illustrates the path of the exchange rate of the yuan with respect to the US dollar. For an approximate period of ten years (1995-2005), exchange stability between the two currencies co-existed, and was located around 8.3 yuan per dollar. However, by the end of 2005, the People's Bank of China (PBC) began a cycle of strengthening the Chinese currency, based on its claim to reactivate its country's economy; in 2014 the yuan reached a record value, and by August 2015 the PBC instructed a wave of devaluations; The intervention of the PBC generated a negative environment in the global financial markets, the financial panic was reflected in brutal falls of the stock exchange in many countries.

China has adopted the challenge of positioning its currency in the global sphere as one of the central axes in the guidelines of its XIII Five-Year Plan in 2016. The country's effort to reach its internationalization began expressly in 2013, with the permission for part of the PBC for the establishment of settlement banks in cities belonging to Asia, Europe and Oceania. Although, currently, even the generality of the transactions of Chinese capital companies are settled in dollars, China's progress is notable: in January 2018, China's currency reached its highest level since December 2015, induced by the weakness of the dollar after the subprime financial crisis, and it does not seem to consolidate completely. 
A weak dollar represents a dilemma, although it generates conditions conducive to economic growth in the very short term, by making US exports more accessible and stimulating the price of basic goods produced; in the medium and long term, a weak dollar transcends to international financial markets, with some consequences such as: increased inflation, less attractive US assets for investors, capital movements and global financial instability. It has been proven that a competitive exchange rate is not the right instrument to promote economic growth, (Guérin and Lahrechel, 2002; López and Perrotini, 2006, Mantey, 2013; Fiorito, 2015); even when under certain scenarios it is a favorable tactic, it must necessarily be accompanied by appropriate monetary and fiscal policies, Vernengo (2010). $[11,12,13,14,15]$

In November 2015, the International Monetary Fund (IMF), on its most recent evaluation of the relative hierarchy of currencies in international financial and commercial systems, considered the yuan as a freely used currency, and it was included as of October 2016 in the basket of currencies that set the value of the Special Drawing Rights (SDR), the weighting percentages for the current five-year period (2016-2020) were determined as follows: $41.73 \%$ United States dollar, 30.93\% euro, $10.92 \%$ yuan, $8.33 \%$ yen and $8.09 \%$ sterling.

The inclusion of the yuan as part of the official reserves of the central banks, both in emerging and European countries, was consolidated in early 2018; a first driving factor for this was the insertion of the yuan in determining the value of SDRs, a second, is the scale of Chinese international trade flows, and a third and essential issuance of convertible petroyuan to gold, which as of now, countries that demand oil, are no longer obliged to buy dollars for exchanging them for fuel. Coupled with this, as a boost measure, China will exempt those who decide to trade with petroyuans from the income tax.

In recent years, the demand for oil by China has grown at higher rates than the rest of the world, 2017 data places this country as the main importer and consumer of oil worldwide, in April 2018 the daily consumption of oil reached 9 million barrels per day, considering a price of US \$ 75 per barrel, the volume of the daily transaction exceeds US $\$ 650$ million, the same dollars amount that China will stop demanding due to the existence of petroyuans.

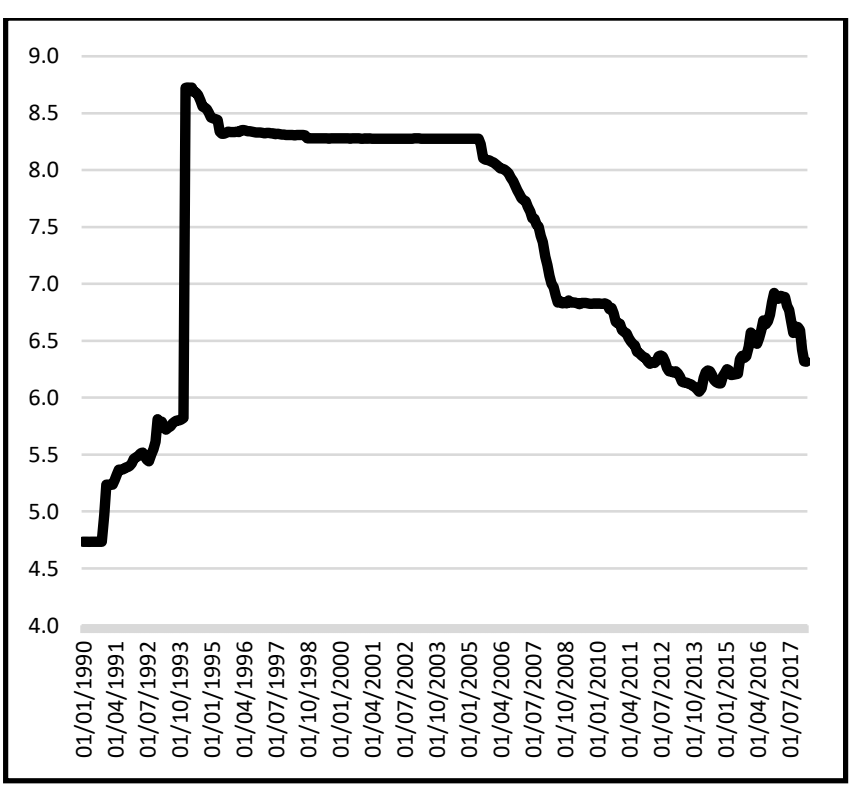

Figure 4. Yuan / Dollar Exchange Rate.

Source: Prepared by author with FRED data (2019).

To support both the yuan and the petroyuan contracts, China's government has established a massive gold acquisition program; The purchase of 454 tons of gold announced in April 2009 was carried out over a period of six years between 2003 and 2009; subsequently the purchase of 604 tons of gold, announced in July 2015, was carried out over a period of six years from 2009 to 2015; from August to January 2016 its gold reserves increased by 100 tons and the trend continues. This propensity for gold is not exclusive of China, countries like Russia, Kazakhstan, Turkey and Belarus have transferred part of their holdings in US Treasury debt bonds to gold ones, the desired goal is to de-dollarize their economies, strengthen their own currencies (primarily the yuan) and boost multinational projects, including the New Economic Silk Road.

Figure 5 shows the gold possessions of China and Russia in the first axis, and those of the United States in the second; Asian reserves still diverge a lot from those of the United States, but the progress is by leaps and bounds, and its effect contributes to the strengthening and internationalization of the Chinese currency; The inclusion of Russia in the analysis, is because it is a relevant ally in the positioning of China; in addition to being its main supplier of oil, both countries have forged a close link to counter economic, commercial and political challenges from the US government.

If the international reserves of both countries are analyzed, leaving aside gold holdings, the gap between the United States and China is abysmal (see figure 7), China has not only increased its gold holdings, its international reserves in general have grown significantly since the beginning of the 21st century; on the contrary, the United States does not need to raise its reserves given the hegemony of the dollar, supported by the credibility and trust that the entire world has placed in this currency. The estimate at the beginning of 2018 , of the world's international reserves, was estimated at US $\$ 11.3$ billion, mostly it is dollars. 


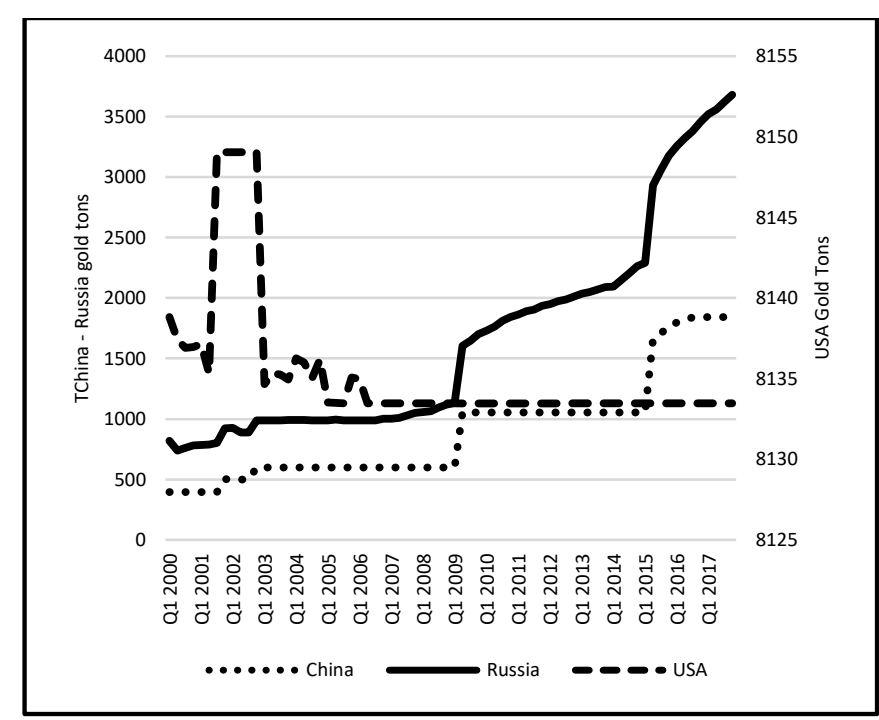

Figure 5. China, Russia and USA gold holdings. Source: Prepared by author with World Gold Council (2019).

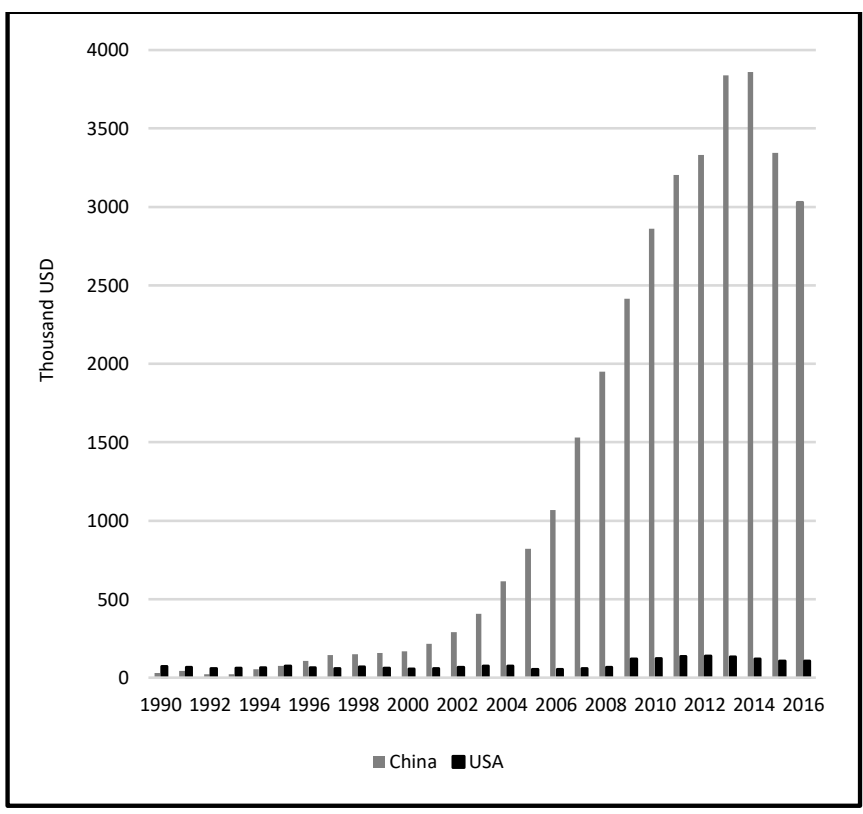

Figure 6. International reserves (Gold holdings not included)

China - USA compared.

Source: Prepared by author with World Bank data (2018).

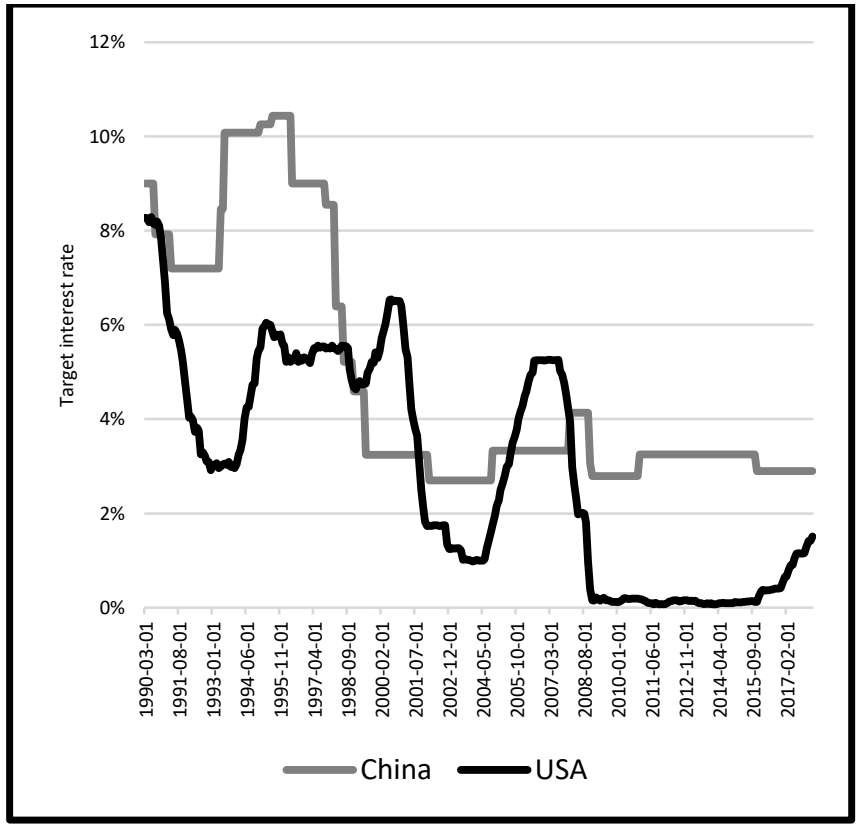

Figure 7. China \& USA Reference Interest Rate.

Source: Prepared by author with FRED data (2018).

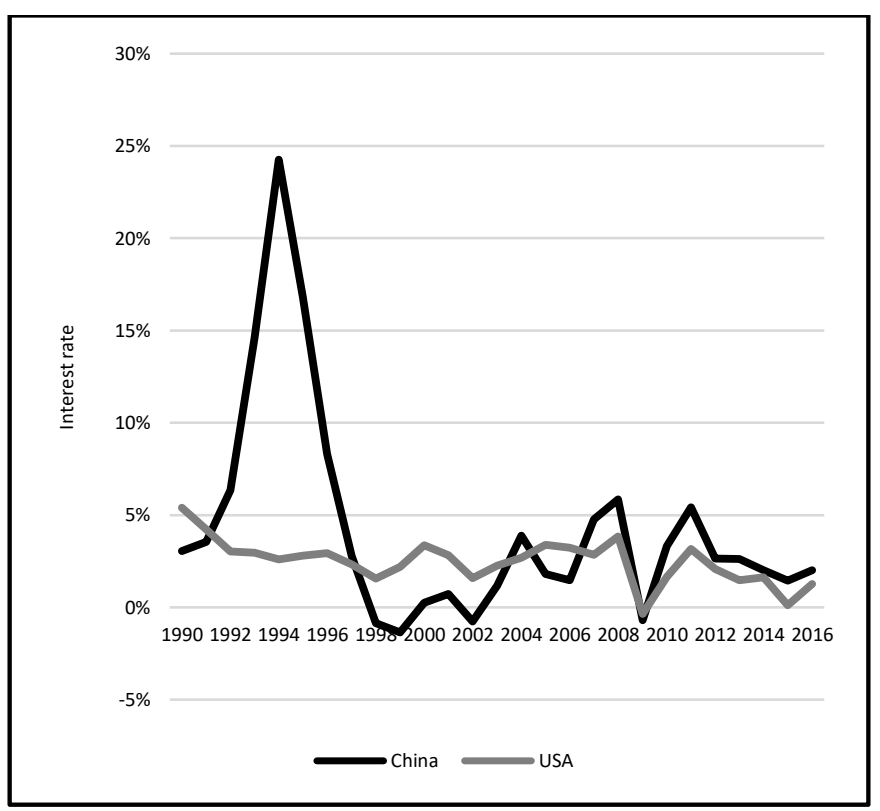

Figure 8. China \& USA Rate of Inflation

Source: Prepared by author with World Bank data

(2018).

The interest rate dynamics differ significantly between China and the United States (see figure 7), While the Federal Reserve (FED) is autonomous from the United States government, the People's Bank of China (PBC depends on the Chinese government, in the first case monetary policy is based on the inflation targeting model, the primary objective is to keep inflation at a certain level and the interest rate is the instrument par excellence of monetary policy; contrary to this, the PBC looks for multiple objectives, inflation control goes to second term, the focus is on containing the risks arising from high 
indebtedness of Chinese companies, reducing financial market speculation and stabilizing the pace of economic growth.

In post-crisis periods, the United States (2001 and 2008) has opted for an expansive monetary policy (low interest rates), the outbreak of the subprime financial crisis placed interest rates at the lowest levels in history, however the recovery has been slow; Meanwhile, in China, since its economic rise, the interest rate has remained relatively stable, recent interest rates of both countries seem to be more linked, given increases by the FED, the PBC has also increased its reference rates to avoid capital outflows that could lead to destabilization of the economy.

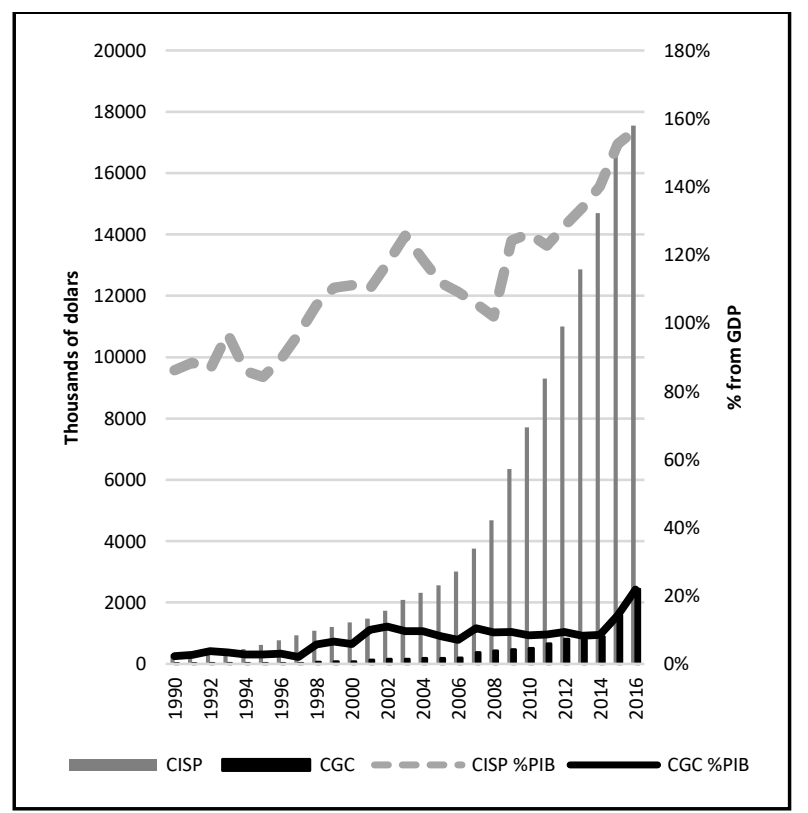

Figure 9. Provided credit to private sector and China's central government.

Source: Prepared by author with World Bank data

(2018).

Figure 8 indicates the inflation rate evolution for the United States and China in the period 1990-2016; the values show some synchrony, except that China lived in the mid1990s an inflationary process from an overinvestment facet, in 1998 and 1999 there was a stage of deflation; and later in the recessive phases of the world economic cycle, some years with deflation were felt like in the United States. After the subprime financial crisis, China's inflation has been slightly higher: food, clothing and housing are among the fastest growing goods.

In previous paragraphs it has been mentioned that China has set out as a primary objective to contain leverage and make proper management of debt, figures 9 and 10 encompass the path of internal credit to the private sector (CISP) and credit to the central government (CGC) for China and the United States respectively, for the period 1990-2016, the values are handled both in thousands of dollars and in \% with respect to GDP (secondary axis); in China the CISP shows a growing trend since 1996, interrupted by the 2007 crisis; in 1996 the CISP was US \$ 772 thousand (89\% with respect to its GDP) and in 2016 it exceeds US $\$ 17,500$ thousand (156.7 \% of GDP), in relation to the CGC, 1995 and 1996 have been the years of greatest growth, exceeding $21 \%$ of GDP, (see figure 9 ). In the United States, the growth rate of the CISP is lower than in China; in the study period the trend is increasing, except for periods of crisis; in 2016, its value is equivalent to $192 \%$ of GDP, (see figure 10); the CGC remained relatively stable from 1990 to 2008, then showed an important growth, from $17.8 \%$ of GDP in 2008 , to $38.5 \%$ of GDP in 2016, reaching a maximum level in 2014 (44.8\% of GDP); The increase of the CGC in the period 2008-2014, is part of the expansionary monetary policy of the FED, which injected liquidity into the economy through the instrument called quantitative easing $(Q E)$, with which the balance sheet of the FED reached US \$ 4.5 trillion, of which $55.2 \%$ are treasury securities and $39.6 \%$ are junk bonds (Mortgage Backed Securities).

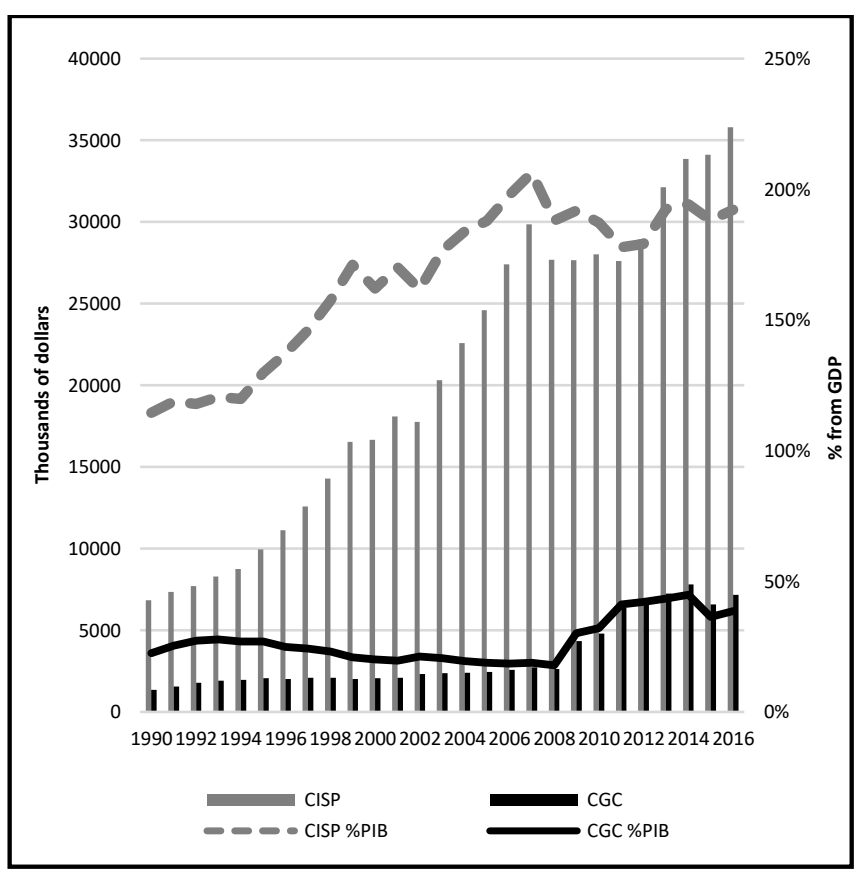

Figure 10. Provided credit to private sector and USA central government.

Source: Prepared by author with World Bank data (2018).

The financial crisis that began in 2008, with an epicenter in the United States, manifested the structural weakening and hegemonic exhaustion of the United States, its financial character penetrated the most intimate core of the so-called global-computing capitalism: with global systemic affectation that impacted relations financial, techno-productive, market, geopolitical, commercial and in the structure of the world order. In spite of this, its overall effect has differed, it hit the countries open to speculative capital flow and neoliberal free market orthodoxy more severely than to the "heterodox" countries, to the extent that the latter had a set of instruments against cyclic that attenuated the negative effects. 
The countries that best contained the effects of the crisis relied on their respective National States, endowed with: solid public financial systems, productive capacity with a high organic composition of capital, healthy international reserves, strong domestic markets and access to regional markets, with self-financing capacity through internal fiscal tools and generation of extraordinary income as a result of international trade. In addition to meeting the above criteria, China served as an encyclical force core that lightened the international crash. While the United States faces the challenge of strengthening its endogenous engines, with a weak post-crisis recovery, China is in full expansion at the international level of its production chains and the accommodation of its excess savings.

\section{Conclusions}

The United States and China are the main economic actors of the current and changing geopolitical environment; this research work is limited to the analysis of the commercial and financial relations forged between both countries, the results are empirical evidence of the consolidated and close bond between the two of them, which transcends their borders, generates a global impact and influences important economic decisions. The United States is still the hegemonic power that leads the world, but the gravitational axis of the international economy has begun a transition process aimed at China, a country that has sought to position itself in various aspects: commercial, military, financial, monetary and economic The findings of the document are condensed in the following points:

- For the period 2001-2017, the United States obtained a deficit trade balance, both in relation to China and the rest of the world, China's position is the opposite: its trade balance with the United States and the rest of the world is favorable; The balance in favor of the United States in its bilateral commercial dealings with China lies in the services section. - In the short and medium term, a two-way causal relationship between US exports and Chinese exports is verified, its external demands are strongly linked, due to the re-exports of the US economy to Mexico - Canada; the domestic demands of both countries show no causal relationship.

- In the monetary field, and while the supremacy of the US dollar shows signs of staggering, China, based on the premise of propping up the yuan and boosting its globalization, has promoted various policies including: the launch of future oil contracts in yuan; stimuli by part of the government for the holders of petroyuans; inclusion of the yuan in the basket of currencies that set the value of the SDRs; and a significant growth in their international reserves, (including gold).

- The interest rate dynamics differs from China to the United States, because of institutional divergences; in China the central bank is not autonomous and inflationary control is a secondary objective, given that the cardinal objective is to contain leverage; In the United States, price control is a priority and the central bank is autonomous.

If the United States and China established harmonious cooperation, the global economy would benefit from it; the political and commercial conflicts generate instability at international level; the disadvantages that the United States currently faces in the debt and trade planes, are not sufficient elements to grant China the status of world leading economy, but if the trends continue, that position for the medium term is not negligible.

\section{References}

[1] Dabat, A. 1993. "El mundo y las naciones". Universidad Nacional Autónoma de México, Centro Regional de Investigaciones Multidisciplinarias (noviembre).

[2] Bernanke, Ben S.The global saving glut and the U.S. current account déficit. Speech 77, Board of Governors of the Federal Reserve System (U.S.). Disponible en: https://www.federalreserve.gov/boarddocs/speeches/2005/200503102/ (consultada noviembre de 2018)

[3] Sutter, R. G. El auge de China y la continuidad de la hegemonía de EEUU en Asia. Real Instituto Elcano (ARI), 89. Disponible en: http://biblioteca.ribei.org/id/eprint/1210. (consultada noviembre de 2018)

[4] Kang, David C. 2009.”¿Liderará Estados Unidos el Siglo de Asia?”. Anuario Asia Pacífico (noviembre): 103-109.

[5] Oviedo, E. D. 2014. “América latina: entre la hegemonía estadounidense y la influencia china". FLACSO-ISA, Joint International Conference, Buenos Aires: Global and Regional Powers in a Changing World (noviembre).

[6] Bendini, R. United States - China relations: a complex balance between cooperation and confrontation. Policy Department, DirectorateGeneral for External Policies. European Union. Disponible en: http://www.europarl.europa.eu/RegData/etudes/IDAN/2016/570464/E XPO_IDA(2016)570464_EN.pdf (consultada noviembre de 2018)

[7] Xinbo, Hu. 2011. "China and the United States Core Interests, Common Interests, and Partnership". Special report 277. United States Institute of Peace, noviembre. [9] Lorig K, Ritter PL, Villa F, Piette JD. Spanish diabetes self-management with and without automated telephone reinforcement. Diabetes Care 2008; 31(3): 408-14.

[8]Schell O. y Shirk S. L. 2017. "Us policy toward China: recommendations for a new administration". Center on US-China Relations, Asia Society's, noviembre

[9] Higueras, G. 2017. "El nuevo orden chino". Documento de opinión. Instituto Español de Estudios Estratégicos (noviembre).

[10] Beeson M, Li F. 2015. "What consensus? Geopolitics and policy paradigms in China and the United States". En International Affairs.

[11] Guérin J. L. y Lahreche Révil A. 2002. « Exchange Rate Volatility and Growth". University of Amiens (CRIISEA). TEAM-CNRS and CEPII (noviembre).

[12] López J. y Perrotini I. 2006. On Floating Exchange Rates, Currency Depreciation And Effective Demand. México: Banca Nazionale del Lavoro Quarterly.

[13] Mantey, G. 2013. “Conviene flexibilizar el tipo de cambio para mejorar la competitividad?". Revista Problemas del desarrollo, UNAM (noviembre): 9-32.

[14] Fiorito A., Guaita N. y Guaita S. 2015. "Neodesarrolismo y el tipo de cambio competitivo". Cuadernos de Economía (noviembre); 45-88.

[15] Vernengo, M. (2010). Una breve nota sobre la política macroeconómica después de la crisis. Circus, otoño 2010, 117 - 127. 